\title{
The Oil Crisis in the Interwar Romanian literature. Three CASE Studies
}

\author{
ȘTEFAN FIRICĂ $\breve{~}^{*}$
}

\begin{abstract}
Different as they are, the poetics of the Romanian avant-garde and of the "young generation" intend to capture the immediate (ir)reality, including its social-political ambiguities. In doing so, they rely on a state-ofthe-art toolkit of literary devices, enriched with techniques taken from genres deemed non-literary, like reportage or diary. We will look into the ways in which Al. Tudor-Miu, Geo Bogza, and Mihail Sebastian reflect (on) the oil crisis in Valea Prahovei, culminating with the 1933 strike, in their reports, poems, or fiction, eventually trying to outline the role of modernist literature in its dialogue with ego- or microhistory.
\end{abstract}

Keywords Ego-history, oil crisis, neoextractivism, avant-garde, Mihail Sebastian.

\section{Political context}

Romania, a significant oil and gas producer in Europe, reshapes its extraction policy after WWI and the constitutional reform ensuing in its aftermath. While the 1923 Constitution attributes subsoil resources to the state and not to the private surface owner (the $19^{\text {th }}$ article), the 1924 Mining Law stimulates the involvement of more companies with major Romanian participation (in terms of management, administrative boards, employees) in the extractive industry. The Mining Law, long debated and strongly lobbied against by foreign companies present on the Romanian market, aligns with the policy of economic nationalism "by ourselves" ["prin noi înșine"], championed by the governing National Liberal Party (NLP), led by primeminister Ion I.C. Brătianu.

\footnotetext{
* University of Bucharest. stefanfirica@litere.unibuc.ro.
}

DOI: 10.26424/philobib.2021.26.2.05 
A new Mining Law, elaborated by the economist Virgil Madgearu, is issued in 1929 by the National Peasants' Party (NPP) soon after their coming to power, in 1928. Its pro-international business orientation mirrors the party's "open door" ideology ["politica porților deschise"], contemplating, in Madgearu's unambiguous terms, "a policy of friendly co-operation with foreign capital. ${ }^{1 \text { " }}$

Despite differences in dealing with particulars, current historiographic accounts converge in considering none of the above-mentioned oil policies as effective as expected when enforced. While it may sound protective with domestic investment, the nationalist approach "by ourselves", supported by the NLP, failed to bring about the promised competitive advantage to local actors in the long run, provided that they had neither the capital, nor the technology operated by big trusts on the global market. The Romanian participation in the industry surged, indeed, after the WWI and the 1924 Mining Law (possibly from 6-8\% to $23-25 \%$ ), ${ }^{2}$ however, the big players in the field still remained Standard Oil and Royal Dutch Shell, through their local subsidiaries Societatea Româno-Americană and Astra Română, respectively, though not functioning at full capacity. Since the small producers were out-scaled in terms of economic leverage, the exploitation of the massive oil reserves in Prahova Valley was underachieved in a period, 1922-1927, when the price of fuel soared to a historical maximum. Therefore, Romania missed the opportunity to export oil in favourable commercial circumstances, under the best financial terms. Later, the "open door" policy was even less fruitful as it overlapped the global economic crisis, leading to the collapse of the export price index to $55 \%$ (in 1930) and then 22\% (in 1931-1936) of the index registered in the years 19231927.3 In the context of the Great Depression, the oil exports, though rising in quantity, brought less revenue to companies and to the Romanian state. The industry contraction after 1930 resulted in wage cuts and layoffs (the so-called "sacrifice curves") operated chiefly among blue-collar workers, like rig drillers, stokers, masons, and transporters, mostly former local peasants stimulated or constrained to reconvert in labour force on the oil fields.

On this political-economic backdrop sparked the Prahova Valley work conflicts of February 1933, among the employees of Astra Română and Societatea Româno-Americană. They overlapped the Grivița railway strike in Bucharest, which received more attention from the media and set off a wave of revolts in other cities of Greater Romania, in times of severe public unrest.

The politically biased press covered the events unfolding in Prahova Valley in less detail, focusing rather on the obscure implications guessed in the backstage of

\footnotetext{
1 Virgil Madgearu, "The New Economic Policy in Roumania," Journal of the Royal Institute of International Affairs, Vol. 9, No. 1 (January, 1930): 95.

${ }^{2} \mathrm{Gh}$. Buzatu, O istorie a petrolului românesc (lași: Demiurg, 2009), 228-229.

3 Bogdan Murgescu, România și Europa. Acumularea decalajelor economice. 1500-2010 (Iași: Polirom, 2010), 246.
} 
the protests. Dreptatea [The Justice], the NPP's official gazette, publicized the governmental narrative about the infiltration of communist agitators in the ranks of blue collars in order to prepare installing the Soviets in the region. The left-wing newspaper Dimineața [The Morning] challenged this narrative endorsed by authorities, reading it as a pretext to force the Parliament to declare the state of emergency and provide the legal framework for armed action against rising workers. ${ }^{4}$ Indeed, the state of emergency was approved within a few days, and the violent repression by the gendarmes and the army followed without further ado.

\section{Literary context}

Interwar literature is prepared to meet the challenges of this new political-economic environment due to, at least, three lines of development growing in parallel.

Firstly, realist fiction is concerned with "mirroring" the surrounding realities of the $20^{\text {th }}$ century, including the new economic development and its related issues, resulting in the rise of specific social "types" and plots. According to the canonical narrative of the national literary history, the local tradition of the realist prose goes back to the $19^{\text {th }}$ century (to "masters" like Nicolae Filimon, I.L. Caragiale, I. Slavici, or Duiliu Zamfirescu), but one can rightfully argue that the years 1910-1920s witness the advent of a new age for the genre, whose first masterpiece is unanimously recognized as the novel Ion by Liviu Rebreanu (1920). More specifically, the literary interest in the economic capitalization of natural resources, by local or foreign investors, is constant, if not growing, in the period. Andrei Terian saw here the conditions for the birth of a new subgenre, the "proto-magical realism, ${ }^{5}$ " as an imaginary defence response of a still-agrarian community facing the foreign Big Capital and its specific neocolonial strategies, from the commodification of natural resources to the othering of the natives. He bases his argument on a few neoextractivist novels published in the 1930s, Cezar Petrescu's series Pământ și cer [Earth and Sky, 1931-1934] and Mihail Sadoveanu's Nopțile de Sânziene [Midsummer Nights, 1934], fictionalizing the oil and lumber extraction in the interwar period, respectively. However, more samples of neoextractivist writing can be provided, dating from the prewar years, like Ion Agârbiceanu's short-stories ${ }^{6}$ and novel Arhanghelii [The Archangels, 1914], dealing with the gold mining in the Apuseni

\footnotetext{
4 See "Dezordini provocate de comuniști lângă Ploiești," Dreptatea, No. 1608 (5 February 1933): 3; "Manifestul guvernului către țară", Dreptatea, No. 1612 (9 February 1933): 4; "Grave tulburări muncitorești la Ploiești și Teleajen," Adevěrul, No. 15057 (3 February 1933): 3; "Grave tulburări la Ploiești," Dimineața, No. 9375 (3 February 1933): 1.

${ }^{5}$ Andrei Terian, "Neoextractivism, or the birth of magical realism as world literature," Textual Practice (Vol. 35, Issue 3): 485.

${ }^{6}$ See short-stories like Vâlva băilor (1909), Duhul băilor (1909), În drum spre băi (1910) in Ion Agârbiceanu, Opere, Vol. II. Schițe și povestiri (Bucharest: Editura pentru literatură, 1962).
} 
Mountains. While Terian's argument about the emergence of a budding ("protomagical realist") subgenre is debatable, the persistence of neoextractivist themes in the Romanian realist prose after the WWI remains beyond doubt.

Secondly, the program of synchronization with the Western cultures, championed by the leading critic E. Lovinescu in the 1920-1930s, facilitates the localization of a new narrative pattern: the semi-autobiographical psychological novel, dramatizing the social-historical circumstances in which the author himself or herself is embedded. The models emulated are mostly French (André Gide, Marcel Proust, André Breton), but the influence of Anglophone literature (Aldous Huxley, John Dos Passos, James Joyce) becomes more apparent in the 1930s. The new poetics of "authenticity" is claimed by more and more writers, spearheading a revolt against the pre-war literary forms. The first in the series, Camil Petrescu melts parts of his own front diary in his novel Ultima noapte de dragoste. Intâia noapte de război [The last night of love. The first night of war, 1930]. Mircea Eliade's Întoarcerea din rai [The return from heaven, 1934] represents bits of the Grivița strike, which took place as recently as the winter of 1933. Mihail Sebastian lends his own traumatizing experience as a Jew during the anti-Semite student riots of 1922-1923 to his fictional hero from De două mii de ani (1935), and drives the course of action into the very recent present. All in all, aiming to capture the flow of events almost in real time, while diving into the subjective perspective of the narrator by the use of modernist narrative strategies (interior monologue, stream of consciousness, diary inserts) the prose of "authenticity" delivers an autofictional account similar to ego-history. ${ }^{7}$ The feminine novel of the sort develops within the same framework, with a lesser accent on political representation (let us not forget that the women's right to vote in general elections was denied by the Romanian Constitution until $1938^{8}$ ).

Thirdly, the avant-garde poetics mushrooming in the 1920s opens the door between literature and journalism, claiming that the former should use the strategies of exploring reality of the latter. The most influential program of the sort is Ion Vinea's 1924 Activist Manifesto for the Youth, which advocates, much in the vein of the Italian futurismo, for the prose importing the economy of means and preciseness specific to the newspaper report ("Today, a good report replaces any long adventure or psychological novel $\left.{ }^{9 \prime \prime}\right)$. Among other things, Vinea's text rejects the turn-of-the-century "art for art's sake," abstracted from the present, in favour of

\footnotetext{
7 Pierre Nora (ed.), Essais d'ego-histoire (Paris: Gallimard, 1987).

8 The women's suffrage was granted only to restricted categories, fulfilling certain criteria concerning age and education. See Ghizela Cosma, Femeile şi politica în România. Evoluţia dreptului de vot în perioada interbelică (Cluj-Napoca: Editura Presa Universitară Clujeană, 2002).

9 Ion Vinea, "Manifest activist pentru tinerime," in lon Pop (ed.), Avangarda românească (Bucharest: Academia Română, Fundația Națională pentru Știință și Artă, 2015), 12 (My translation).
} 
a writing strategy designed to capture the "here and now" and to go overtly political: even this poem takes on the guise of a street manifesto, featuring some turns of phrase and graphic matrices characteristic of placard slogans ("Down with the Art $(. .$.$) "; "WE WANT:/ the wonder of the new word (...)"; "SO:/ Death to the epos-like$ novel ${ }^{10 "}$ etc.). Only the humorous undernote twinkling through the lines of the poem tones down the revolutionary impact, finally shaping it into a mostly literary experiment. Despite its playfulness, however, one of the points on the Romanian avant-garde agenda regards the renegotiation of the relationship between arts and politics. The contact zone between the two crosses the journalistic space, frequented by many avant-garde artists, conceiving their writing as a form of committed activism.

\section{Journalistic context}

The end of WWI also witnesses the reinvention of the reportage as a genre in the Romanian journalism under foreign influences, with the development of communication technologies intensifying the circulation of media content between different cultures. The most popular models of the times are the French réportage $d^{\prime}$ 'aventure and the American "yellow journalism, ${ }^{11 "}$ seeking sensationalism and scandal mongering to meet big audiences. Energetic arguments on the mission and strategies of modern report involve authors of various generations and ideological allegiances, like Camil Baltazar, Panait Istrati, Mihail Sebastian, Ion I. Cantacuzino. In the generalist newspaper Vremea [The time], Geo Bogza initiates a column to debate the particulars of the genre with established writers and journalists like N.D. Cocea, Felix Aderca, Mircea Eliade, N. Davidescu, and F. Brunea-Fox, in 1934 ${ }^{12}$. A weekly magazine started in 1933 is entitled, and for good reason, Reporter. Another magazine, Realitatea ilustrată [The Illustrated Reality], dedicates many of its pages to photo-reports taken on-site, such as "Petrol," a lucid investigation into the technological and economic inequities in the drilling fields of Prahova Valley. ${ }^{13}$

But the most consequential contribution to the reformation of the journalistic genre, in what regards narrative structures, is made by the relatively small-sized phalanx of avant-garde artists, grouped around marginal publications like Contimporanul, unu, Punct, Integral, Alge and other short-lived and financially challenged local ventures. Following the main lines of the group's program, the

\footnotetext{
$10 \mathrm{lbid}$.

11 Radu Ciobotea, Reportajul interbelic românesc. Senzaționalism, aventură și extremism politic (lași: Polirom, 2006), 7-9.

12 A faithful synopsis of these debates is provided in Mihai Lisei, "Reportajul românesc interbelic. Teme și dezbateri (II)," Studia Universitatis Babeș-Bolyai. Ephemerides, 1 (June 2011): 155-172.

13 Ionel Munteanu, “Petrol,” Realitatea ilustrată, No. 279 (2 June 1932): 13-15.
} 
young Geo Bogza militates for what he calls "the pure reportage," apt to convey the crude reality with cinematic means. He also draws the ironic draft of a writer's manual of good practices, in which he advises giving up the "literature of comfort," which traditionally delivers convenient "solutions to come to terms with the world," mostly "idealistic and metaphysical," concocted by teachers of philosophy. In contrast with these unreliable mental constructs, the writer should stick to "the image held on our retina," which is "the only truthful" thing we have at hand. ${ }^{14}$ Like a reporter, the writer should express the reality stored in his own senses, keeping away from the misleading abstractions fabricated by philosophy or ideology. The ethical profession de foie sketched here by Bogza is that of a relentless empiricist, suspicioning any discourse of political manipulation, that is, any discourse except the one produced according to one's own direct perception. As we will see immediately, his practice as a journalist and poet follows closely in the footsteps of this theoretical approach.

Paul Sterian, a peculiar intellectual mixing together avant-garde and narrowly Christian Orthodox views, also promotes "report-poems" or "aggressive poems" as a subgenre, which he also calls "of knife and blood. ${ }^{15 "}$ Such cruel texts will write his friend and colleague, Geo Bogza.

\section{Reports and report-poems}

Before dwelling on Geo Bogza's prose and poetry, widely appraised by literary historians, we should look at the less popular texts authored by his friend, Al. TudorMiu. In 1926, when Bogza settles in the village Buștenari having left behind the childish dream of becoming a mariner, Tudor-Miu lives in the neighbouring town, Câmpina. Both writers are involved in down-to-earth businesses to earn their living, Bogza running a tiny soda factory with his elder brother, and Tudor-Miu working for the Concordia-Electrica company. However, in the meantime, they enthusiastically share a couple of journalistic projects: the 1928 avant-garde review Urmuz is written entirely by Bogza and Tudor-Miu, after the third issue; the local gazette Strada [The Street], managed by Tudor-Miu in 1932-1936, hosts some of their reports and poems treating the events happening in Prahova Valley.

Tudor-Miu's 1934 volume, Standard. Poeme de petrol și energie [Standard. Poems of petrol and energy], bears less resemblance to Walt Whitman than it seems to promise. Its title suggests the involvement of poetry into the economic reality of the region. Moreover, the insertion of the American brand on the book cover implies

\footnotetext{
${ }^{14}$ Geo Bogza synthesized these ideas in two texts published in the same issue of the journal unu: "Reportajul pur" (undersigned with his pseudonym André Far) and "Profesie de credință pentru grupul Alge," unu, No. 35 (May 1931).

15 Paul Sterian, "Poezia agresivă sau despre poemul reportaj," (My translation), Ibid.
} 
the brutal intrusion of the capital in life and, therefore, in art. The dedication announces, somehow elliptically, a poetics of immediacy: "the poems in here are onsite. ${ }^{16 "}$ For instance, the poem Șomaj - Epocă [Unemployment - Epoch] sketches a landscape typical of the Prahova Valley in the 1930s, with "constructions of steel skeletons," "factories with dead souls" deserted, while the surrounding towns are swarming with poor people turned into potential criminals, in times of need: "The army of blacksmiths, stokers, day-labourers,/ defeated by hunger, is loafing on the streets./ The steely gaze of vultures on the prey,/ on swinging hands of fat men, full of rings. ${ }^{17 "}$ The poems of the volume showcase the transition from the symbolistexpressionist hazy atmosphere of apocalypse to the abrupt notation of "here and now" details, specific to the Romanian avant-garde. The eclecticism is also mirrored in the economy of the verse, usually observing the rules of traditional prosody (in terms of rhythm and rhyme), which confers the modernist ensemble an awkward tinge of retro style.

In contrast, Bogza rebuffs any out-fashioned pathos, to focus on the "pure" events unfolding before his eyes, that he has the opportunity to follow from close distance, as a journalist and poet. On 10 May 1929, he signals, in Bilete de papagal, the tragic circumstances of a driller's death, set ablaze after allegedly falling in a crude oil tank. Under the neutral title "Fapt divers petrolifer" [Oil anecdote], the reporter tells blankly the circumstances of the fatality: "His sister told me. Nicolae Ilie had sold his parcel, he had 17.000 lei on him. In the fatal day, he drank from morning till evening, then went to the drill to sleep. And here, he caught fire. ${ }^{18 \prime \prime}$ Actually, the event had taken place as early as the end of September 1928, as we may find out from Bogza's diary: "28 September 1928. In the evening, a boy comes and announces: "Niculae Ilie, a driller from Gloria, caught fire and burnt. The whole village is drunk. I am leaving to take care of him. Horrific. He is fetched to the Corporation, on a stretcher. From here, they take him with a Cadillac and then with a Ford to the hospital in Câmpina. Dirty with his excrements. ${ }^{19 \prime}$ Seven months after the mishap, Bogza recalls it probably to oppose its official explanation as an accident, while he suspects a first- or second-degree murder. A week later, the same review publishes his poem "Nicolae Ilie. Fragment", packed with haunting images of the body, with "hands as black as coals" and "eyes like roasted chestnuts. ${ }^{20 "}$ Bogza will

\footnotetext{
16 "poemele de față sunt la fața locului" (My translation), Alexandru Tudor-Miu, Standard. Poeme de petrol și energie (Câmpina: Strada, 1934), 7.

17 "Armata făurarilor, a fochiștilor, a pălmașilor/ învinsă în foame colindă pe străzi./ Priviri oțelite de vultani, pe prăzi,/ pe mâinile inelate, legănătoare, ale grașilor" (My translation), Ibid., 65 .

18 George Bogza, "Fapt divers petrolifer," Bilete de papagal, No. 384 (10 May 1929): 2 (My translation).

${ }^{19}$ Geo Bogza, Jurnal de copilărie și adolescență (Bucharest: Cartea Românească, 1987): 166.

${ }^{20}$ George Bogza, “Nicolae Ilie. Fragment”, Bilete de papagal, No. 385 (17 May 1929): 3.
} 
amplify and rewrite this poem time and again, adding new shocking snapshots, for instance providing an expanded account of the ensuing "olfactory terror, ${ }^{21 "}$ i.e., the remembrance of the smells exhaled by llie's burnt body, in a follow-up published in the Surrealist review unu, not before long.

Life and work in the drilling fields of Valea Prahovei continue to serve as a source of inspiration for the journalist and writer, who, in 1932, undersigns the column "Buștenari, Runcu, Mislea" with the pseudonym T.U.Z., in the newspaper Strada from Câmpina. A future novelette probably finds a starting point in a report telling the story of a cereal magnate going mad. ${ }^{22}$ Mixing blurry allusions with pinpoint details, social empathy with streams of black humour, the author reports in the same vein a theft, a settling of accounts between local pub owners, followed by a police enquiry, or the work conflict burst at Teleajen refinery, in February 1933. Short as it is, one of strongest pieces published in Strada reports the reconversion of ex-workers, after massive lay-offs in the industry, into what they traditionally were, i.e., land labourers. Bogza imagines the peasants taking off their "American boots" to put back on their "peasant shoes". The final paragraph suggests, tongue in cheek, returning from the industrial to the agricultural local economy: "Where there used to be oil rigs, now they grow pumpkins. The oil rigs melted down one after the other, like black sugar lumps. ${ }^{23 \prime}$ Bogza holds on to his principle of delivering memorable snapshots to picture a local phenomenon that we may call the re-peasantization of the proletariat.

However, the two masterpieces of his series of texts regarding the oil crisis are two poems, "Bolnavul peisaj petrolifer" [The sick oil landscape] and "Poem petrolifer" [Oil poem], both written in 1932. Appeared on the front page of the same newspaper, Strada, the former illustrates a poetics of shock, based on the analogy between the industrial landscape and the decayed organic: the field pierced with rigs squirting oil resembles a purulent body infested with a deadly or venereal disease: "The hill is a sick old man with no chance to heal,/ inside, petroleum is like a horrible syphilis or cancer chancre,/ and it is black and it is ugly,/ and flowing over the greasy,

21 Geo Bogza, "Nicolae Ilie. Teroarea olfactivă", unu, II, no. 14 (June 1929). Massively reshaped, these two pieces will feature, together with other parts of the poem, in Bogza's 1978 volume of poems Orion.

22 See Geo Bogza, "Criză, șomaj, mizerie," under the column title "Buștenari, Runcu, Mislea," Strada, No. 1 (June 1932): 3. For the relationship between this fictionalized report and the novelette Cum a înnebunit regele petrolului, written in 1939 (Geo Bogza, O sută șaptezeci și cinci de minute la Mizil, Bucharest: Editura pentru literatură, 1968, 109-132), see Paul Cernat, Vase comunicante. (Inter)fețe ale avangardei românești interbelice (Iași: Polirom, 2018), 172.

23 "Pe acolo pe unde erau sonde, azi cresc dovleci. Sondele s-au topit una după alta ca niște bucăți de zahăr negru" (My translation), Geo Bogza, "Pe acolo pe unde erau sonde, azi cresc dovleci," Strada, No. 2 (July 1932): 3. 
infamous valley,/ more infamous than the least of prostitutes. ${ }^{24 \prime}$ A tinge less shocking and more subtle is the latter poem, where crude oil signifies not only literally the raw material used in the industry, but also life, in all its brutality, before being distilled in the refineries of art: “(...) all I told you so far/ is not a cry of revolt for the fate of the betrayed women and drillers,/ but the beginning of an anthem for the oil and for the crimes of its men,/ the beginning of an anthem for those capable to lie, to cheat, and to steal,/ the beginning of an anthem for myself and for my brothers in infamy./ I do not love oil as a pure essence in test tubes,/ I love it as it is getting out of the earth, dirty, by dirty means,/ I love it furiously, passionately,/ and I want to sing my terrifying race of oilmen. ${ }^{25 "}$ We can read here a manifesto in the vein of Tudor Arghezi's aesthetic of ugliness, but also a violent confession de foi against le lyrisme pure illustrated by the likes of Ion Barbu. Bogza engages a daring dialogue with two of the most influential national authors of the time. The semantics of his poem gains in amplitude, ranging from the 1:1 photography of life and death in Prahova Valley to abstract issues of modernist poetics, without losing its poignancy. Geo Bogza recommends himself as a faithful follower of Walt Whitman's claim of contingency, in opposition with the abstruseness of Stéphane Mallarmé or Paul Valéry's literary projects, in vogue in certain intellectual circles of Europe and Romania, as well.

\section{One novel and five ideological readings}

Part Three of the novel De două mii de ani [For two thousand years, 1934] by Mihail Sebastian also conveys the recent events having taken place in Prahova Valley, showcasing the semi-autobiographical prose's aim to capture immediate reality. Beyond the fictional regime and despite the writer's consistent concern to rule out almost any connection with real-life models, ${ }^{26}$ the novel had something of a roman $a$

\footnotetext{
24 “Dealul e un bolnav bătrân și fără lecuire/ înăuntru păcura e ca o plagă oribilă de cancer și de sifilis/ și e neagră și e urâtă/ și curge în vale onctuoasă și infamă/ mai infamă decât cea din urmă dintre prostituate" (My translation), Geo Bogza, "Bolnavul peisaj petrolifer," Strada, No. 4 (4 September 1932): 1.

25 "fiindcă tot ceea ce v-am spus până acum/ nu e deloc un ţipăt de revoltă pentru soarta femeilor şi a sondorilor înşelaţi/ ci un început de imn pentru petrol şi pentru mârşăviile oamenilor lui/ un început de imn pentru acei care sunt capabili să mintă, să înşele şi să fure/ un început de imn pentru mine şi toţi fraţii mei întru infamie/ eu nu iubesc petrolul când ajunge esenţă pură în eprubete/ ci îl iubesc aşa cum iese din pământ, murdar şi prin procedee murdare/ îl iubesc cu furie, cu pasiune/ şi vreau să cânt rasa mea teribilă de oameni ai petrolului" (My translation), Geo Bogza, "Poem petrolifer," unu, No. 49 (November 1932): 4. ${ }^{26}$ Mihail Sebastian, Cum am devenit huligan, in Opere, Vol. I (Bucharest: Academia Română, Fundația Națională pentru Știință și Artă, 2011), 605. In the same writing, Sebastian admits that the only exception to this rule is Ghiță Blidaru, based on his university teacher and model Nae lonescu.
} 
clef, as proved by one of the author's notebooks, in which the characters are straightforwardly associated with the persons they were based on: the fictional chief-architect Mircea Vieru with the writer Camil Petrescu, the professor of political economy Ghiță Blidaru with the professor of logics and metaphysics Nae Ionescu, the Marxist S.T. Haim with the communist activist Belu Zilber, the architect Marin Dronțu with the right-wing journalist G. Racoveanu, etc. ${ }^{27}$ At some point in the course of action, the hero-narrator, loosely based on the author's biography, quits Law School to study architecture and enter the construction crew involved in building a mining town, with modern office and residential housing, on the old site of the village Uioara, now displaced and renamed Uioara Nouă [The new Uioara]. So, the novel's first-person voice is assigned to a technocrat, an employee of the American investor, engaged in the process of radical industrialization in Valea Prahovei.

In the first place, we should notice that this homodiegetic narrator rarely, if ever, approaches the workers' issues, which were central in the real unfolding of events, as we could notice. On the contrary, the novel's fictional space accommodates no character belonging to the labouring class (driller, stoker, mason, etc.), while plein-air scenes involving hills and valleys, wells and rigs, extractions, eruptions, spüllung, accidents are practically missing, the narrator spending most of his time philosophizing behind closed doors, depicting soirées and romantic affairs in the milieu of white-collar employees. We learn of the workers' rising dissatisfaction only by proxy, from incidental conversations between the intellectuals moving around, and the moment when the strike goes off catches the narrator at the company's headquarters in the central Rosetti Square, Bucharest. Here, the more and more alarmed telegrams coming from Valea Prahovei reach the bureaucrats, until finally accountant Hacker's car, driving straight from Uioara, stops by, "with two punctured tyres, an overheated engine about to ignite, a shattered windscreen and the half the hood torn away. ${ }^{28}$ " The damaged automobile, bringing about panic in Rosetti Square, reminds of the taxi "with the windows broken, the door slightly bent, one headlight off, cracked, ${ }^{29}$ " making the turn around the central statue in Brătianu Square, Bucharest, announcing the outbreak of the Grivița strike, in Mircea Eliade's novel Întoarcerea din rai. It is relevant that Sebastian and Eliade, close friends and

27 Ibid., 1194. Sebastian insists on the disconnection between fiction and reality also in his 1935 polemic article "Voluptatea de a fi scriitor. Romanul cu cheie". See Mihail Sebastian, Opere, Vol. VI (Bucharest: Academia Română, Fundația Națională pentru Știință și Artă, 2014), 1017-1020.

28 Mihail Sebastian, For Two Thousand Years (Penguin Classics, 2016), 201. Translated by Philip Ó Ceallaigh.

29 "cu două cauciucuri plesnite, cu motorul înfierbântat, gata să ia foc, cu parbrizul sfărâmat, cu capota pe jumătate smulsă din încheieturi" (My translation), Mircea Eliade, Întoarcerea din rai (Bucharest: Garamond, 1995), 159. 
sharing the same literary views at that time, wrote and published their novels of "authenticity" practically simultaneously. Both prefer to look at the events happening at the outskirts of society from the privileged position of the centre. We could infer a philosophy of representation different from Geo Bogza's: the writer's focus is on Rosetti or Brătianu Square, where periphery can only send its messengers. What happens "on-site" is less inspiring to these narrators than to the poetic voices of Tudor-Miu and Bogza. The events that really matter are unfolding in the employer's office, or on the architect's board, i.e., in the places where ideas are born to potentially effect changes in the world. Eliade and Sebastian's shared point of view is intellectual-elitist, and it has everything to do with their commitment as leading representatives of the (mostly centre and right-wing) Young Generation of the 1930s, claiming the "primacy of the spiritual" over the economic and the social-political. ${ }^{30}$

This is why Sebastian's novel seeks an ideological reading of events, compensating for the scarcity of information collected from the scene. To be more precise, the data entering the main office in Rosetti Square are already structured and half-ideologized:

"However vague the information we've received so far, it seems there are two distinct movements in Uioara, though they're both caught up in the same storm. The first group is made up of refinery, factory, and oil workers, all from Old Uioara. Then there are the viticulturists in New Uioara. The first group have wage demands, while the second group ask for nothing. They just want to go down to Old Uioara and destroy it. The oil revolt and the plum-tree revolt."

The narrator and his intellectual circle reflect more than once on the distinction between what they call "the oil revolt" (in original, revolta sondelor, i.e., "the oil-rig revolt") and "the plum-tree revolt". The former is a metonym for the revolt of oil-labourers, and the latter represents the uprising of cultivators, who see their fruit-trees covered with spüllung (i.e., a fine dust spread everywhere, a byproduct of the extraction process) and their crops compromised. The question which the narrator dwells on is whether the events in Valea Prahovei can better be described as workers or peasants' unrest. Is it the reaction of the poor proletariat activating in the underfunded industry, in times of economic crisis, or the backlash of ex-land owners having lost or sold their concession to the mining company? In the

\footnotetext{
30 See Eliade's 1927 generational manifesto "Itinerariu spiritual," in Mircea Eliade, Profetism românesc, Vol. I (Bucharest: Roza vânturilor, 1990), 19-78.

${ }^{31}$ Mihail Sebastian, For Two Thousand Years, 202.
} 
polyphonic manner typical of the modernist aesthetics, intended to nest for ambiguity and multiple perspectives, the author provides four parallel ideological answers, assigned to four of his characters: the American company boss, Ralph T. Rice; the chief-architect Mircea Vieru; the Marxist activist S.T. Haim; and the nationalist-antimodernist professor of political economics, Ghiță Blidaru.

Rice, the owner of a global enterprise with unabashed neocolonialist outlooks, articulates the predictable discourse of a cynical businessman for whom issues like mentalities or ecology are parenthetical, in the triumphant quest for capital. Such "minimal", "inevitable" collateral damage should not be taken seriously by an industry insider: "Nonsense, sir. It's clear you don't know the oil business. There are inevitable risks. And they're usually minimal. And what's a plum tree at the end of the day? ${ }^{32 "}$

Vieru, the architect employed to construct a refinery, an office building and a villa district in Uioara, has the discourse of a technocrat. He is the urban designer washing his hands of any social-political implication of his work. However, his modernism is geared in a political-economic context that he refuses to acknowledge, raising absurdly the claim of artistic autonomy: "I don't care about your wells. Whether you're extracting petrol, vegetable oil or why, it's all the same to me. ${ }^{33 \prime \prime}$ Actually, it's Vieru who comes up with the idea of moving the village Uioara from its old site, in order to build the industrial town in its stead, from scrap. After an initial hesitation, Rice accepts his radical solution as the most efficient in terms of costs and benefits. For Vieru, it is only the most profitable aesthetically. At the end of the day, different as they are, their economic and artistic interests meet in the common project of industrialization. Therefore, Vieru sees the workers' revolt as an attempt against the monopoly of modernism, a stupefying reaction against the dominant direction of the $20^{\text {th }}$ century.

Despite his involvement on the workers' side, the communist S.T. Haim is hardly less cynical than Rice and Vieru in his political practice. Far from the oilfield where the unrest is unfolding, in the lush casino of Sinaia, he paradoxically declares his support for the oil enterprise, as a historical opportunity that should be grabbed by the communists. Heavy industrialization boosts the proletarianization of peasantry, an indispensable step to raise class consciousness and eventually unleash a political revolution apt to overthrow imperialist capitalism in the long run: "Very interesting, everything Vieru's attempted there. You're working for us. You're making this entire region proletarian. In fact, you're doing something even more serious: you're dissolving the antagonism between the peasants and the proletariat. Another superstition that's disappearing. No sir, you can't have rural reaction in the

\footnotetext{
32 lbid., 99.

33 Ibid., 101.
} 
middle of fighting for the revolution etc. ${ }^{34 \prime}$ Haim follows interestedly the workers' revolt and even seems to be one of its instigators, ending up behind bars as a political prisoner. This unflattering portraiture of Marxist action represents echoes the official narrative about the communist interference in Prahova Valley.

On the contrary, Ghiță Blidaru considers the unrest not as an "oil-rig", but a "plum-tree revolt." Industrialization is harmful because it means uprooting, both literally and metaphorically: its agents tear apart living fruit trees, as well as living traditions. Blidaru's radical interpretation draws on Herder's romantic ideology of preserving local identities against the waves of modernization, toned up with the violent antimodernist stereotypes circulating in the interwar years: "What you're doing there is barbarous, criminal. It's the most artificial thing that's been done in Romania since 1848. ${ }^{35}$ " The "criminal" "artificiality" of Westernization (having started with the 1848 revolution), displacing the ancient indigenous "authenticity", is one of the core claims made by the right and far-right Romanian activists of the period.

After outlining this complex ideological field in which he sees himself captive, as an intellectual and as a Jew, Sebastian's narrator negotiates his own position, trying to accommodate the project of modernization with the extant natural-cultural heritage. His private solution features an undertone of naive environmentalism, as reflected in the villa he is commissioned to construct on the shore of lake Snagov, in the last part of the novel. As Blidaru, the plot owner, grants him full freedom of aesthetic choice, he opts for a light and airy modernist design with simple lines, integrated in the surrounding nature: "It is the house I dreamed of. A house built for sunlight. Evenings, its shadows fall cross the water, like the shadow of a plant. ${ }^{36 "}$ Metaphorically, the narrator positions himself halfway between Vieru and Blidaru, aiming to implant the modernist project in the soil of a moderate localism. Having confronted the conflicts sizzling in the Romanian society of the 1920s-1930s, he finally finds comfort in a poetics and a politics of moderation and inbetweenness, which has everything to do with his Judeo-gentile pro-integration outlook ${ }^{37}$. He maintains the same balanced attitude when considering all the different, if not conflicting, readings of the conflict in Valea Prahovei. Like his narrator, Sebastian is interested in capturing all the perspectives, except for one: the workers', which, conversely, interest Tudor-Miu and Bogza exclusively.

\section{Conclusion}

Overruling the old prejudice against "literature romanticizing history," the interwar poetics of sincerity and directness aimed to reset the connection between literature

\footnotetext{
34 Ibid., 110.

35 Ibid., 117.

${ }^{36}$ Ibid., 231.

37 See Paul Cornea's argument for considering the novel's narrator a Judeo-gentile, starting from Edgar Morin's typology, Ibid., 1237.
} 
and history. Writers belonging to the avant-garde (Al. Tudor-Miu and Geo Bogza) or to the Young Generation (Mihail Sebastian) fictionalized social-political moments such as the work conflict in the oilfields of Valea Prahovei, by including in their stateof-the-art literary toolkits techniques of "non-literary" genres like reportage or diary, to inject the freshness of on-the-spot notation. There are also relevant differences in the ways in which Tudor-Miu and Bogza, on the one hand, and Sebastian, on the other, look at events: factual vs ideological focus; blue collar vs white collar point of view; left vs centre-right orientation.

Beyond aesthetic and political particulars, we tried to showcase how modernist writing - reportage, poetry, fiction - could provide valuable guidance to recuperate forgotten pieces of ego- or microhistory in the interwar period. By revisiting the private dramas of the real persons involved in the big picture, by restoring the ad-hoc ideological horizon, in all its complexity and ambiguity, we are given the chance to peep behind the stereotyped version of dominant historiography. For that matter, the official communist discourse crassly manipulated the representation of the 1933 strikes, in Prahova Valley and Grivița Railway Yards, going so far as to counterfeit historical iconography, in order to construct a mythology of the local communist party, including illegal activists like the future leaders Gheorghe Gheorghiu-Dej and Nicolae Ceaușescu. In Teleajen, near Ploiești, a plaque commemorating the 1933 events was unveiled in 1958, during Gheorghiu-Dej's regime. The text, erased after the 1989 revolution, praised the workers' revolt in the wooden language of the propaganda:

"On celebrating 25 years since the February 1933 heroic fights of the railway and oil workers from Refinery no. 3, then called Romanian-American, we solemnly unveiled this commemorative plaque, on the site where the oil workers, under the guidance of the Romanian Communist Party, raised to fight against exploitation, for welfare, freedom, and peace. ${ }^{38 \prime \prime}$

Tudor-Miu and Bogza's reports and poems, as well as Sebastian's novel can help us grasp the reality behind this piece of wooden language etched on the plaque. We can always read literature as an antidote against the risk of preserving a single (historiographic) narrative.

38 "Cu prilejul sărbătoririi a 25 de ani de la eroicele lupte din februarie 1933 ale ceferiștilor și petroliștilor, la rafinăria nr. 3, fostă Româno-Americană, a avut loc solemnitatea dezvelirii unei plăci comemorative, pe locul unde muncitorii petroliști, sub conducerea P.C.R., s-au ridicat la luptă împotriva exploatării, pentru bunăstare, libertate și pace" (My translation). See: http://republicaploiesti.net/2020/03/misterul-monumentului-gol-din-colonia-teleajen.html (Last access: October 2021). 